\title{
Nostalgia, Kitsch and the Great Recession in Margaret Atwood's The Heart Goes Last AND WESTWORLD (SEASON 1)
}

\begin{abstract}
The paper is a comparative study of Margaret Atwood's 2015 dystopian novel The Heart Goes Last and the 2016 HBO science-fiction TV series Westworld (Season 1) created by Jonathan Nolan and Lisa Joy. Drawing upon Susan Faludi's The Terror Dream and Marita Sturken's Tourists of History, the paper focuses on the American frontier myth, and the concepts of nostalgia and kitsch (in particular, Sturken's symbol of the snow globe) to analyse both works as cultural reactions to the recent Great Recession. While both analysed works can be said to reflect an anxiety about the growing class gap and express resentment against the rich, they respond differently to the popular demand for comfort in times of crisis. While Westworld uplifts with a vicarious experience of the underdog's emancipation, Atwood's satire ironically withholds a happy ending, providing readers with a lesson and a challenge instead.
\end{abstract}

\section{Keywords}

Nostalgia; kitsch; camp; the American frontier myth; financial crisis; class; gender; violence

The aim of this article is to compare Margaret Atwood's novel The Heart Goes Last and the first season of the HBO TV series Westworld created by Jonathan Nolan and Lisa Joy. Both works will be read as cultural reactions to the recent Great Recession which use nostalgia combined with kitsch as tools of criticism of the contemporary Western, in particular American, economic and class system. I derive this central idea of kitschy nostalgia or nostalgic kitsch from two books, both published in 2007: Susan Faludi's The Terror Dream. What 9/11 Revealed 
about America and Marita Sturken's Tourists of History. Memory, Kitsch, and Consumerism from Oklahoma City to Ground Zero.

Both books are critical analyses of the post-9/11 culture in the US and are very detailed in their topicality. However, in both books, as Faludi's title signals very clearly, the goal is to reveal something fundamental about the USA, namely the lasting impact of America's central myth of the frontier, in particular the myth of American innocence and righteousness. Faludi and Sturken recognise the myth as the very foundation of the country, based on the experience of the early settlers, and cultivated ever since with the help of a culture of patriotic nostalgia employing kitsch as its most visible material expression. In her book, Faludi concentrates on the gender aspects of this myth, where the homeland is always femininised and its small-scale equivalent is the home, the domestic sphere, inseparably equated with women. Both home and homeland need traditionally masculine protectors: individual men and public institutions, especially the military, which, as in any patriarchy, is dominated by men. While commentators on the myth of the frontier usually focus on the positive, especially the American dream, freedom and possibilities, Faludi foregrounds the negative reality behind it; as she says, the first American settlers "dwelled in a state of perpetual insecurity" (2007: 211). According to Faludi and Sturken any new insecurity (such as, recently, the 2007-8 global financial crisis and its aftermath) brings the American culture as if back home: back to the original insecurity and to measures aimed at preserving that first home. ${ }^{1}$ Both authors recognise this in the mainstream domestic reactions to the 9/11 terrorist attacks (but also earlier: e.g. in the Cold War) and criticise the ensuing political and military rash actions in the absence of rational reflection. In particular, wondering how or if this repetition of the past pattern could be avoided in the future, Sturken examines the material culture of commemoration as a means of processing tragedy and trauma. She demonstrates how it provides comfort that channels emotions in alignment with the original myth of American innocence: the attacked innocent and now even more emasculated feminised home(land) needs justified defence by its patriarchal protectors, who ought to be supported in their dominant role. This knee-jerk reaction causes entrenchment and repetition of the past and effectively forestalls any political debate and possible change which could help prevent future repetition of tragedy and trauma, not only on American soil. Such a debate is further preempted by the mainstream commemorative culture's selective, sentimental and shallow engagement with the past, which Sturken calls tourism of history. Sturken's central symbol for it is a kitsch object, a popular souvenir, the snow globe.

A snow globe is a fragment of the world in miniature with its own logic. As Sturken writes,

[f]or each, the intended gesture is to give the globe a shake, to temporarily fill it with a kind of metaphoric dust, and then to let it settle back down. Each demands a constant animation, a repetition of the shaking of the globe world. Yet the point is that it returns to its original state, that the dynamism of the shaken globe settles down into calmness. This is the desire embed- 
ded in the snow globe, that [...] the chaos of being shaken up will predictably settle down. (2007: 284-285; added emphasis)

The snow globe is a confined and controlled environment that relies on the principle of repetition. Repetition guarantees predictability; predictability equals safety, which - despite temporary change - includes the safety of the overall status quo.

The metaphor of the snow globe and its attributes can also be applied to the two worlds created in The Heart Goes Last and Westworld - two works which, in addition, in their own ways recycle elements of the abovementioned foundational myth, even if essentially challenging the idea of innocence. Both stories are set in the US in the near future, which is a few decades more distant and more technologically advanced in the case of Westworld. Atwood's dystopian novel envisages an experimental Consilience/Positron "twin city" (52), built as a solution to the post-economic-crash complete collapse in the American north-east. The novel's protagonists, a young married couple, Charmaine and Stan, have lost their home after Stan lost his job, and are living in a car, under constant threat of rape and murder from zombie-like gangs of the starving unemployed. They decide to join the privately-run project and sign a contract agreeing to spend every alternating month in prison in return for enjoying every following month in their own home in a safe and clean town with zero unemployment.

The town is designed in the 1950s style: "The fifties was chosen for the visual and audio aspects, because that was the decade in which the most people had self-identified as being happy" (59) - and "maximum possible happiness" is one of the project's goals (59). The 1950s, an early stage of the Cold War, also happens to be the golden age of the Hollywood Western. True to the nostalgia present in the period it emulates, the twin town of Consilience/Positron relies on the idealised image of the American frontier. In the introductory workshops for the new arrivals: "They themselves, the incoming Positron Planners" - are told that - "they're heroic! [...] They're like the early pioneers, blazing a trail, clearing a way to the future [...]. Posterity will revere them!" (53). However, this is a Margaret Atwood novel - posterity will not revere them in the end. The whole project will turn out to be a front for several seriously criminal activities: prisoners' euthanasia for harvesting and sale of transplant organs, rumoured sale of babies' blood as a rejuvenating panacea, production of Possibilibots - sex androids, including Kiddybots, as well as organised kidnapping of unwitting people and turning them into sex slaves through neuroengineering. At the outset, Stan and Charmaine merely give up all their rights to be voluntarily imprisoned in their new repetitive cycle: not only in the Positron prison where they perform unpaid labour, but also in the retro-style town of Consilience: they can't leave or even communicate with the outside world.

Perhaps even more snow globe-like is Westworld, the amusement park in the TV series. It is owned by Delos Incorporated and its god-like creators and operators supervise it by literally towering above its round interactive 3D map. Its hosts are uncannily realistic androids that are in every sense of the word imprisoned in 
the park to serve the affluent guests, called newcomers. These guests could also be called tourists of history in an extreme version of Sturken's term: the park is Wild West-themed and feigns time-travel - back to approximately the times of the Civil War (1861-65). The place is predicated on the nostalgic notions of adventure and freedom central to the myth of the frontier. The best illustration of how this romanticised simplification of history is simplified even further for immediate consumption comes from one of the hosts, Maeve, a madam in a brothel, who repeatedly says to her potential new customers: "this is the new world. And in this world, you can be whoever the fuck you want." "Welcome to Westworld: live without limits" is how the park is advertised: the park guarantees total discretion and innocence. "No judgments. No questions" - whatever the guests' escapist and predominantly brutal pleasures may be, after serving them the hosts and the scene are cleaned up by invisible Delos employees. The literal dust, like snow in a snow globe, settles back down.

If most parts of both descriptions of Consilience/Positron and Westworld sound like a futuristic (but not entirely implausible) fantasy, at the same time some other aspects reflect a truism about any innovation, including a technological one, whether it marks "progress" (a relative term) or not. Both experimental worlds literally push and cross pre-existing limits and set new frontiers to be crossed later, while simultaneously drawing upon the old frontier, the original one. Both contemporary imaginary futures reimagine the past. From the reader's/ viewer's perspective, both involve temporal overlap: between the present, the future, and the past. Atwood's near-future reality in many ways feels so close to home as to seem like an alternative general present reality and not some imaginary future, ${ }^{3}$ while the plot of Westworld is particularly complicated because it is so non-chronological. The very experience of temporal confusion induced in the viewers of the show may be said to convey some "metacommentary" about time, its fluidity, repetitiveness, and inherent ungraspability.

A major shared characteristic of both fictitious worlds is that they are essentially thought experiments. They both pose numerous "what if" questions - typical not only for Margaret Atwood in particular, but for science fiction and speculative fiction in general. In such questions technology meets philosophy: they address artificial intelligence, consciousness, memory, emotions, neuroengineering, complete power, complete freedom, free will, the meaning of life, of being happy, of what it means to be real, and more. I am not going to explore here ontological and posthumanist or transhumanist issues, but as I signalled at the beginning, my goal is to interpret The Heart Goes Last and Westworld as products of the Great Recession era. Atwood's novel was published in 2015, but its first version was serialised as an e-book in 2012-13, still during the Great Recession. ${ }^{4}$ Westworld was released in ten episodes in 2016 - the year when post-recession nostalgia played such a major role in American politics and continues to do so. Thus, both works' nostalgic snow globe-like reenactments of the past, relying on the past, clinging to the past, manipulating it and using it for their own purposes are very much part of a larger - present - trend. 
Like a number of other cultural responses to the Great Recession in various media forms, The Heart Goes Last and Westworld can be said to express an anxiety about the growing gap between the exploitative all-powerful rich and the exploited powerless rest of society, ${ }^{5}$ especially the working class, the poor and the homeless. Questions of having a home and/or feeling at-home are also crucial in both works under discussion. Both works depict confined and completely controlled spaces - snow globes of order and predictability - which contrast with the outside world, in both works and outside them. Furthermore, both isolated spaces are manufactured simulacra of bygone reality, managed by elite boards of investors, and created and maintained at a considerable cost, but also generating huge profits for the owners. Additional profits come from pursuing covert agendas: it is hinted at that Delos Incorporated is working on other applications for Westworld's AI technology, presumably military; while the Consilience/Positron project becomes involved in serious crime mentioned earlier. In both stories one co-founder of the enterprise rebels against the other and conspires to destroy it, horrified by what it has become. In both works the rich in general, and the company owners and their wealthy clients in particular are depicted with a great deal of resentment, although considerably more so in Westworld. In a carnivalesque suspension of the outside world's norms and mechanisms, within the two brave new worlds' boundaries the innocent go to prison on the one hand, while on the other hand people who engage in simulated (or real? if later on the hosts/victims develop consciousness, memory and perhaps even psychological trauma?) acts of rape and murder walk free, and, in fact, can be respected pillars of society. Is it incidental that the innocent who go to prison are very poor, while those who engage in what looks like acts of rape and murder with impunity are very rich? In the novel, the rich are the only people who "can afford to have police" (18), and are "floating on tax-free platforms just outside the offshore limit" (13). Also offstage are their obscene pursuits: only the rich can afford the state-of-the-art sex bots (including those for paedophiles) and kidnap sex slaves. The TV series depicts both most of the high-ranking employees of Delos and the park's guests, regularly referred to as "the rich bastards" or "the spoilt rich bastards," as morally bankrupt, despicable, vulgar and pathetic in their baseness. Even if they visit the park with their children and act civilly, they still engage in something that remains in bad taste; no matter how beautiful the landscapes, the frontier is fake and like perhaps in any form of tourism various degrees of kitsch are unavoidable. In particular, an amusement park is kitschy by definition: as Sturken observes, "[r]eenactment is a key feature of much kitsch" (2007: 26) and "escapism is essential to most definitions of kitsch" (2007: 19).

Thus, while encouraged to feel contempt for the rich human guests, we, as viewers, can't help but sympathise with the android hosts, especially the two most prominent ones and the oldest: Dolores, looking like a beautiful young white woman, and already mentioned Maeve, modelled as a beautiful black woman. All the hosts, male and female, are routinely used as objects for shooting practice or other kinds of violence and/or sex, but Dolores and Meave are specifically 
designed to be sexual objects: Maeve is a prostitute, while Dolores is a damsel in distress, her distress being mainly (gang) rape. The TV series' depiction of female characters is as interesting as it is problematic. As two critics, from the New York Times and Entertainment Weekly have said, Westworld "questions nihilistic entertainment impulses while indulging them" (Poniewozik 2016), because

it wants to have it all ways. It asks questions about entertaining with violence, but make no mistake, it is violent entertainment. [...] Dolores' story is a tale of violence against women, a cliché of TV violence against women, a comment on the cliché of TV violence against women, and a question: How do we move beyond this? (Jensen 2016)

But, as the same critic admits, "using violence against female characters, or any character, is a cheap way to hook an audience" and "at the risk of affirming the strategy, I'm invested in Dolores and Maeve" (Jensen 2016).

What this last sentence reminds us is the fact that just as the TV series is about a large financial undertaking of a large corporation, the TV series itself is a large financial undertaking of a large corporation, the Time Warner Conglomerate, which owns HBO. Just as the board of investors of the amusement park make balanced decisions and investments to try and spend reasonably to gain the most, the creators of the entertaining TV show make analogous choices to sell their product and benefit from it. For this to happen, in both cases the customers need to be satisfied; after all they also invest in the product they buy and expect returns in the form of being successfully entertained. In my view, the TV series strikes the necessary balance well: it is sufficiently advanced in terms of special effects to compete with other available shows and films increasingly raising the bar for one another; it throws in enough philosophical questions and quotes from Shakespeare to keep the more intellectual audiences stimulated; while not overwhelming audiences seeking other kinds of stimulation of which there is also a great deal, but perhaps just about short of enough to really offend. It is striking that racism and expressly racist violence are completely absent from the amusement park (as far as we know) and the show - a significant portion of which is interested in a region still being taken away from Native Americans in the period around the American Civil War. On the other hand, there are plenty of images of sexism and misogyny.

Especially disturbing is the consistency with which the show captures women's battered, cut or bloodied faces. On the whole, in Westworld's Season 1 we can see more violence against men; there are many more mutilated and dead male bodies, perhaps simply because the American frontier was such a "man's world," and only men fought in the Civil War. However, there is an undeniable difference in how mutilated male and female bodies are presented. Mutilated and especially dead male bodies frequently appear in large numbers, anonymous, as in scenes of robbery or mass shooting. In contrast, scenes of violence against women predominantly focus on their faces, which are often on display in repeated and/or long close-ups, including extreme close-ups, which recur with fetishistic insistence. 
All the female faces covered with their own blood belong to almost all the prominent female characters (Dolores, Maeve, Theresa, and especially Clementine, the one exception [so far] being Charlotte [perhaps owing to her unfeminine power status referred to below]). These victims of violence are not anonymous, and thus the violence against these women becomes more individual and personal - it is highlighted that a female character (as a person) is destroyed and had suffered before being killed, while the violence against the many male nameless and characterless bodies (especially of men utilised as soldiers) is banalised and rendered unremarkable. In the three cases where prominent and named male characters are covered with blood (William, the Man in Black, Logan), in two of them the blood is somebody else's (a defeated enemy's). There is a repeated close-up on Logan's face cut by William in the scene where William becomes the alpha male, while naked Logan is being humiliated. Interestingly, another bloodied male face (Hector's) is clearly used - together with the rest of his naked body - as a tool for proving another character's alpha status - this time a woman's. When one woman hitherto in a position of power, Theresa, is being replaced by another woman, Charlotte, the latter flaunts her dominant sexuality in front of the abashed beta female. In both cases those characters who - somewhat theatrically - objectify the male body acquire full control. Objectification of the female body is entirely casual and carries no such symbolic significance. Overpowering a male body (carrier of the phallus and thus the signifier of power) empowers. Overpowering a female body (the signifier of weakness) does not raise the level of already possessed power.

My interpretation of this compromise in political correctness, i.e. absence of racism but presence of sexism and misogyny in Westworld, is that while the sexism and misogyny strategically sprinkled here and there all over the show satisfy those nostalgic about the times when women knew their place, at the same time any offence caused to those feminist-minded is offset by the prominence of several female characters, white and black, in positions of power, especially in the ending of Season 1. This is where I find the biggest return that all viewers can receive from their investment in the series. Its first season ends with several hosts developing consciousness, morally triumphing over humans, because, as their co-creator, Dr Robert Ford says, they, unlike humans, can change through their choices, and finally, they appear to begin an uprising against their oppressors. Significantly, the two leaders of this rebellion are Maeve and Dolores. Maeve's processing powers are far superior to human, and Dolores, who previously was programmed to be unable to pull a gun's trigger, now shoots her maker (albeit by his own choice and design) and utters the final words: "I understand now. This world doesn't belong to them. It belongs to us." In this way she claims the park's territory for herself and her kind and declares androids - now the hosts not only nominally - at home in the world created for them by humans as their prison. The versatile gratification from this ending comes from the fact that many can enjoy the potential comeuppance for "the rich bastards" - especially in a post-recession era. Westworld androids are the ultimate underclass, the exploited working class 
(their existence is very hard work without any compensation), a TV-friendly version of the slaves airbrushed from the Western-like setting. Anyone who considers themselves an underdog - a conservative white male or the feminist woman who (from his point of view) oppresses him together with the brown-skinned (illegal) immigrant - they all could identify with the androids and take pleasure in the vicarious experience of their change of fortune and hopefully, in Season 2, well-deserved revenge and victory.

Tales bringing comfort and hope for change are certainly in high demand, especially during and after a crisis, such as the recent economic one. It remains to be seen whether Westworld, and popular culture in general, contribute to more discussion about social change by offering inspiring images and symbolism, as well as meaningful representation of the underprivileged, or provide only the kind of consolation which Marita Sturken (2007) identified in commemorative culture - a palliative, and in the end a distraction from and a substitution for any change in the real world. ${ }^{6}$

Undoubtedly, discussion of contemporary political matters with the aim to warn, educate, and activate readers has been taking place on the pages of Margaret Atwood's novels for many years, and The Heart Goes Last is no exception, regardless of its light, often humorous tone. Despite the many similarities between the novel and the TV series, the two works, of course, belong to entirely different media - any novel, especially by such a renowned author, is a very different financial undertaking from a TV series (in addition: in its first season). Atwood doesn't aim to please the largest possible readership. She offers readerly pleasure and a few enjoyable plot twists, but no titillating scenes of sexual violence - which she does address, but theoretically, in terms of consent and ethics. ${ }^{7}$ Nor is there any uplifting happy ending, although Atwood ironically plays with the idea. In fact, the whole book is playful, satirical, often comedic. ${ }^{8}$ It also makes much more use of kitsch; in fact, the reviewer J.W. McCormack has described the entire novel as "[g]lorious, sequined, pencil-thin mustache, midnight movie trash" (2015; original emphasis). Kitsch is especially visible when certain issues, in particular nostalgic notions of gender, are being ridiculed by Atwood. Both main characters are cartoonish, and we are not seriously invited to invest in them (luckily for Stan and Charmaine, who thus escape physical harm). They are not even very interesting or engaging: their marriage is stale, their initial predicament is harrowing but they plod on; when offered to join Consilience/Positron they instantly give up all of their rights and freedoms without a single reflection - after all "you can't eat your so-called individual liberties, and the human spirit pays no bills" (54). Even if Stan is at times slightly sceptical about how the project is being marketed to them, they just play along for a year. Especially Charmaine fits in perfectly back in the 1950s and the period's ideal of femininity. Her character is particularly like a caricature: a throwback to before the second wave of feminism: she doesn't even recognise her whirlwind extramarital affair as sexual liberation; it is presented as something merely hormonal she has no control over. ${ }^{10}$ When she is not being "not herself" once a month, ${ }^{11}$ she is naïve, kind and gentle, obedient to the 
point of gently euthanising troublesome prisoners because she is told that this is her job and she is very good at it.

It is exactly such compliance and thoughtlessness as a result of devaluation of civic ideals and principles in light of other priorities taking over - and not so much what the characters do as what they never do and never question - that becomes a telling illustration of the additional costs of a catastrophic economic crisis pointed out by Atwood. ${ }^{12}$ Stan and Charmaine, an average, previously middleclass couple with jobs and a mortgage, agree to go to prison just to be safe and not homeless. In fact, they are thankful for being selected for the scheme advertised as an opportunity available only to some - "Be the person you've always wanted to be!" (38). They only become involved in a plot against the project as unwitting tools. But after the scheme has been exposed in the media and shut down, ${ }^{13}$ little changes for the larger system and for them alike. There is no news of the crisis abating. "[B]ig money ha[d] a lot invested in Positron" (426) and "more than a few of $[\ldots]$ respected politicians $[. .$.$] were big backers" (434). For this reason$ there is no real investigation into the matter, and the co-founder of the project, Ed, betrayed by his former partner, Jocelyn, instead of going to trial and, ironically, to prison, will be given false documents and smuggled abroad. "You really think I'd want him giving full testimony in front of Congress?" - says Jocelyn - "Spilling all the beans? I myself am one of those beans. [...] No clean hands at this party" (434). As some commentators of the scandal say in the book: "these utopian schemes always went bad and turned into dictatorships, because human nature was what it was" (426). It's the snow globe situation again: the whole issue will be cleaned up, all the shaken snow will settle down. And sooner or later a new scheme will be proposed and backed - perhaps even by the same people - and implemented only to cause yet another collapse, etc.

Of course, the same problem of culpability - yet impunity, and the consequent cyclicality typifies economic crises in capitalism. "The last four hundred years have been replete with economic crises" say Charles P. Kindleberger and Robert Z. Aliber in their Manias, Panics, and Crashes. A History of Financial Crashes (2011). Also Carmen M. Reinhart and Kenneth S. Rogoff point to "[t]he persistent and recurring nature of financial crises in various guises through the centuries" (2009: 273) in their book entitled This Time is Different. Eight Centuries of Financial Folly. "The lesson of history" - they write - "is that even as institutions and policy makers improve, there will always be a temptation to stretch the limits. [...] Technology has changed, the height of humans has changed, and fashions have changed. Yet the ability of governments and investors to delude themselves" - to believe "this time is different" - "giving rise to periodic bouts of euphoria that usually end in tears, seems to have remained a constant" (Reinhart and Rogoff 2009: 291-292). ${ }^{14}$

Atwood has written about such repetitive mechanisms and "human nature" for decades, most prominently in The Handmaid's Tale. ${ }^{15}$ Accordingly, instead of much needed comfort in her (post-)recession-era novel, she offers a lesson, albeit in an entertaining form. In the book's last sections, Charmaine and Stan 
are happily back together after Charmaine's neurosurgery. It was meant to make her fall in love with Ed, who had kidnapped her for sexual purposes, but as part of the plot's larger twist, Charmaine is made to "imprint" on and become completely devoted to her husband. "[I]t doesn't seem right" to her that she had never consented to the operation, to which her husband was not subjected, but "it feels right" (441; original emphasis), and the couple are happy. She believes that "everything's so wonderful" (454), even though "Stan can still get a little impatient with her in daily life" (454). They renew their vows, and "the wedding is pure enchantment" (435) - it takes place in Las Vegas and its description is a festival of kitsch and camp in which Atwood's writing becomes reminiscent of that of her friend, Angela Carter. At the same time, the wedding is an echo of Shakespeare's comedies, ${ }^{16}$ and the Shakespearean reference is yet another thing which The Heart Goes Last has in common with Westworld. Shakespeare's comedies and camp share their connection to gender, and all three depend on performance.

As we read in Susan Sontag's "Notes on 'Camp,"”

Camp sees everything in quotation marks. It's not a lamp, but a 'lamp'; not a woman, but a 'woman.' To perceive Camp in objects and persons is to understand Being-as-Playing-aRole. It is the farthest extension, in sensibility, of the metaphor of life as theatre. (2018: 9)

Lorna Irvine has observed that "[ $t$ ]he allure of artificiality informs all of Atwood's writing" (2000: 207), and the same can certainly be said about Carter's works, which, however, are much more often imbued with an ebullient camp style. In The Heart Goes Last Atwood's modified fairy tale ending forms an intertextual link with Carter's The Bloody Chamber, a collection of modified fairy tales. At the Las Vegas wedding, which should be popular culture's cliché happy ending, Jocelyn tells Charmaine that she has a gift for her, which she will deliver in a year's time. Exactly a year later, like a good fairy or a wicked witch, she visits Charmaine, now a mother of a little daughter. Jocelyn reveals to Charmaine that there never was any operation, she does not have to love and be with her husband, and she is "free to go" (457). Delivering this message Jocelyn paraphrases one of the final lines of John Milton's Paradise Lost about Adam and Eve being sent away from Eden: "The world is all before you, where to choose" (457), to which Charmaine responds: "How do you mean?" (457).

The novel ends with this question: with $a$ question, instead of an answer. As if the good fairy or the wicked witch (Margaret Atwood herself?) came to us, the readers, and gave us a puzzle to solve for ourselves. The question of choice is also one of the crucial aspects of the ending to Westworld's first season. It is the newly developed ability to choose, to decide, that makes the androids evolve over the final frontier and become human (or even more or better than human). The first choice that is made, by Maeve, is altruistic: it is to rescue another android that was programmed to play the role of her daughter. The robots' relationship becomes real as a result of Maeve's decision. Ironically, Charmaine's renewed relationship with her husband is a result of her assumed inability to make her 
own decisions, which she in fact prefers, in effect becoming a robotic Stepford Wife. ${ }^{17}$ Jocelyn sees through her: "You want your decisions taken away from you so you won't be responsible for your own actions? That can be seductive" (Atwood 2015: 457). Despite the differences between them, both (post-)recession era works, The Heart Goes Last and Westworld end on the side of outgrowing ignorant innocence, embracing responsibility, as well as the "so-called individual liberties, and the human spirit," even if it "pays no bills" (Atwood 2015: 54). But while Westworld uplifts with its vision of rebelling against and possibly defeating the rich and soulless, Margaret Atwood brings us down to earth reminding us of the snow globe-like nature of the world in which we, humans, have lived for a very long time. Similarly to what Susan Faludi and Marita Sturken undertook in their books about America, Atwood wonders and warns us about worrying recurring patterns in America and beyond. Because even if the current exploitative rich and powerful could be satisfactorily overthrown (which is very unlikely) - then what?

\section{Notes}

$1 \quad$ Analysing what she calls "the cultural troika of media, entertainment, and advertising," Faludi concludes that "[i]n the post-9/11 reenactment of the fifties Western, women figured largely as vulnerable maidens" (2007: 5), while "[t]he media seemed eager to turn our designated guardians of national security into action toys and superheroes" (2007: 47). All the marketing slogans for Westworld are usefully available in text form via the Westworld website, itself a marketing device for Westworld.

In fact, such a reality is not alternative in certain parts of the US, not to mention many other parts of the world. An example of this is the real town of Flint, Michigan, which is the subject of Netflix's 2018 documentary series Flint Town and which features prominently in the 2018 documentary film Fahrenheit 11/9 by Michael Moore (who was born in Flint himself). The town seems to have served as one possible source of inspiration for Atwood, who even mentions tap water being "rusty red in colour" (Atwood 2015: 20), which may be a reference to the real town's real water crisis, further exacerbating the conditions of unemployment, poverty and crime. Admittedly, various sources provide different time frames for the Great Recession. In Capital in the Twenty-First Century, Thomas Piketty states that the Great Recession is not yet over in 2013, the year of the book's original publication (472).

$5 \quad$ See e.g. most articles in the two collections: Boyle and Mrozowski (2013), and Negra and Tasker (2014).

6 The recent increased activism is the US justifies some optimism, especially the \#MeToo Movement, in which Evan Rachel Wood, the actor who plays the role of Dolores, is herself an outspoken activist as a rape survivor (Jensen 2018).

7 An instance of this, in addition to the sexual crimes involved in the Consilience/Positron project, is the fact that the novel's main female character was sexually abused as a child by her own father.

8 One critic describes the novel as a "[j]ubilant comedy of errors, bizarre bedroom farce" "[a]t first a classic Atwood dystopia, rationally imagined and developed, it relaxes suddenly into a kind of surrealist adventure. The satirical impulse foregrounds itself. [...] Atwood allows her sense of the absurd its full elbow room; her cheerfully caustic contempt [...] goes unrestrained" (Harrison 2015). 
$9 \quad$ For more on kitsch in The Heart Goes Last see Howells 2017; for more on kitsch and camp in Atwood's earlier works see Irvine 2000.

10 To be fair, Stan, who also engages in an extramarital affair, albeit against his will, is at the same time a "puppet of his [...] desires" (225).

11 The meetings with her lover, who lives in "her" house with his wife while she and Stan are in prison, take place on switch-over days at the beginning of every month, when Stan and Charmaine switch places with their "Alternates" and go to/return from prison.

12 Sturken sees this danger even in times of economic stability in the US - in "the equation of citizenship and consumerism and the selling of consumerism as the avenue to freedom, democracy, and equality" (2007: 59).

13 Atwood envisages her own version of an amusement park, after the closing down of Consilience/Positron: "Maybe a modified version. [...] Maybe condos, for the prison end of it, with a tourist attraction ensuite. Jailhouse Rock, they would call it. They've done prison conversions like that in Australia. My guess is people would pay to role-play in there, don't you think?" (Atwood 2015: 434).

14 Aliber is not alone in predicting that the next such "euphoria," "the next major period of rapid credit expansion" and the next real estate bubble will implode in 2020 or 2025 (Kindleberger and Aliber 2011: 272, 301).

15 It is very telling about our present times that the novel became serialised to great acclaim by Hulu in 2017. Furthermore, Atwood has announced that a sequel to the novel, titled The Testaments, will be published in September 2019 (Cain 2018).

16 To quote one reviewer, "the novel ends like a Shakespearean comedy with every character $[\ldots]$ romantically paired with another based on no demonstrable chemistry" (McCormack 2015).

17 The term has been popularised by two (1975 and 2004) film adaptations of the 1972 novel by Ira Levin, The Stepford Wives.

\section{References}

Atwood, Margaret (2015) The Heart Goes Last. New York, Random House.

Boyle, Kirk and Daniel Mrozowski (eds.) (2013) The Great Recession in Fiction, Film and Television: Twenty-first Century Bust Culture. Plymouth, UK: Lexington Books.

Cain, Sian (2018) Margaret Atwood announces The Handmaid's Tale sequel, The Testaments. The Guardian, 28 Nov. https://www.theguardian.com/books/2018/nov/28/margaret-atwood-announces-the-handmaids-tale-sequel-the-testaments (Accessed on 7.12.2018).

Carter, Angela (1985 [1979]) The Bloody Chamber. Harmondsworth: Penguin Books.

Fahrenheit 11/9 (2018) Michael Moore. Midwestern Films.

Faludi, Susan (2007) The Terror Dream. What 9/11 Revealed about America. London: Atlantic Books.

Flint Town (2018) Zackary Canepari, Drea Cooper, Jessica Dimmock. Netflix.

Harrison, M. John (2015) The Heart Goes Last by Margaret Atwood review - rewardingly strange. The Guardian, 23 Sept. https://www.theguardian.com/books/2015/sep/23/the-heart-goes-last-margaret-atwood-review-novel (Accessed on 20.02.2018).

Howells, Coral Ann (2017) True trash: genre fiction revisited in Margaret Atwood's Stone Mattress, The Heart Goes Last, and Hag-Seed. Contemporary Women's Fiction 11(3), 293-316.

Irvine, Lorna (2000) Recycling culture: kitsch, camp and trash in Margaret Atwood's fiction. In: Nischik, Reingard M. (ed.), Margaret Atwood: Works and Impact. Rochester, NY: Camden House, 202-214.

Jensen, Erin (2018) Evan Rachel Wood details sexual assaults to Congress. USA Today, 28 Feb. https://www.usatoday.com/story/life/people/2018/02/28/evan-rachel-wood-details-sexual-assaults-congress/381118002/ (Accessed on 12.03.2018). 
Jensen, Jeff (2016) Westworld: Entertainment Weekly review. Entertainment Weekly, 30 Sept. http://ew.com/article/2016/09/30/westworld-review/ (Accessed on 20.02.2018).

Kindleberger, Charles P. and Robert Z. Aliber (2011) Manias, Panics, and Crashes. A History of Financial Crashes. $6^{\text {th }}$ edition. NewYork: Palgrave Macmillan.

Levin, Ira (2002 [1972]) The Stepford Wives. New York: Perennial.

McCormack, J.W. (2015) Margaret Atwood's wonderfully trashy dystopia. The New Republic, 2 Oct., https://newrepublic.com/article/122995/margaret-atwoods-wonderfully-trashy-dystopia (Accessed on 29.11.2018).

Negra, Diane and Yvonne Tasker (eds.) (2014) Gendering the Recession: Media and Culture in an Age of Austerity. Durham and London: Duke University.

Piketty, Thomas (2014 [2013]) Capital in the Twenty-First Century. Trans. Arthur Goldhammer. Cambridge, Massachusetts, London, England: The Belknap Press of Harvard University Press.

Poniewozik, James (2016) Review: 'Westworld' is a provocative but flawed sci-fi shoot-'em-up. The New York Times, 30 Sept. https://www.nytimes.com/2016/10/01/arts/television/review-westworld-is-a-provocative-but-flawed-sci-fi-shoot-em-up.html (Accessed on 20.02.2018).

Reinhart, Carmen M. and Kenneth S. Rogoff (2011) This Time is Different. Eight Centuries of Financial Folly. Princeton and Oxford: Princeton University Press.

Sontag, Susan (2018 [1966]) Notes on 'Camp'. Notes on 'Camp'. London: Penguin Books, 1-33.

Sturken, Marita (2007) Tourists of History. Memory, Kitsch, and Consumerism from Oklahoma City to Ground Zero. Durham and London: Duke University Press.

Westworld website. https://discoverwestworld.com/\#about (Accessed on 18.02.2018).

Westworld. Season 1 (2016) Jonathan Nolan, Lisa Joy. HBO.

Ewa Kowal is an Assistant Professor in the Department of Comparative Studies in Literature and Culture in the Institute of English Studies at the Jagiellonian University in Kraków, Poland. She is the author of The "Image-Event" in the Early Post-9/11 Novel: Literary Representations of Terror after September 11, 2001 (Jagiellonian University Press, 2012) and a series of articles devoted to post-9/11 literature and film. Her current project concerns cinematic and novelistic depictions of the 2007-8 global financial crisis and its aftermath. She is interested in feminist theory and criticism, gender studies, masculinities studies, happiness studies, housing studies, film and the visual arts.

Address: Dr Ewa Kowal, Department of Comparative Studies in Literature and Culture, Institute of English Studies, Jagiellonian University in Kraków, al. Mickiewicza 9A, 31-120 Kraków, Poland. [email: ewa.kowal@uj.edu.pl] 
